\title{
打設直後からの乾燥途中におけるコンクリートの含水状態 \\ 仕上げ材下地としてのコンクリートの含水状態の検討 その 1 \\ DRYING OF CONCRETE FROM JUST AFTER CAST \\ Study on moisture behavior in concrete substrate for finishing layers - Part 1 -
}

\author{
橋田浩*, 田中享二**, 小池迪夫*** \\ Hiroshi HASHIDA, Kyoji TANAKA and Michio KOIKE
}

\begin{abstract}
Premature failures, such as blistering or exfoliation, of finishing layers applied directly on concrete substrate are mainly attributed to excessive moisture in concrete. It is thus important to investigate moisture behavior in concrete before and after layers are applied on it. Moisture distribution in concrete with normal slab thickness is experimentally observed during drying from just after cast in this paper, part 1. The moisture distribution is observed by two measuring methods; one is done by measuring pore humidity in concrete and the other is weighing broken pieces of concrete for the determination of moisture content. Then the drying behavior is estimated by the numerical calculation based on the theory according to Bažant et al., and the drying model at early age of concrete proposed by the authors.

Drying of concrete proceeds very slowly, and much moisture exists in concrete for a very long period. It is basically concluded that drying for longer period in less humid ambience is more desirable for application of layers. It is also found that calculated values, both pore humidity and moisture content, agree well with experimental results at early period up to a few months.
\end{abstract}

Keywords : concrete, finishing layer, pore humidity, moisture content, moisture diffusion

\section{1.はじめに}

下地コンクリート面に施工される防水層，合成高分子 系床材等の仕上げ材にははく離，ふくれといった欠俩が しばしば発生する。これらの欠陥には種々の要因が複雑 に影響しており，すべての欠陥のメカニズムを明確に説 明することは容易ではない。しかし，欠陥の生じた仕上 げ材と下地コンクリート境界に大量の湿気や水分が存在 していることから，欠陷発生には水分の影響が最も顕著 であると考えられる。近年の工期短縮，ポンプ压送のた めの軟ねりコンクリートの普及, コンクリートの乾燥の 不十分さは，特に憂慮される問題である。本研究は，以 上の観点から，仕上げ材の欠陥防止に関する基礎資料を 得るために，コンクリートスラブ打設後の乾燥途中なら びに仕上げ材施工後における含水状態の変化を明らかに することを目的としている。

コンクリートの乾燥過程における含水状態についての 研究は, 乾燥収縮の観点から検討したものとして, 水分 の移動が拡散方程式に従うとし，その非線形性を指摘し
た Pickett の研究 ${ }^{1)}$, Bažant $ら^{21}$ の湿度分布の非線形拡 散解析，阪田ら ${ }^{3)}$ の水分逸散に基づいた実験および数值 解析による研究など多数ある(1) 10)。また, Nilsson ${ }^{11)}$ は 筆者らと同様に仕上げ材下地としての観点から，コンク リートの特性および含水状態について検討している。こ れらの中のいくつかは乾燥に伴うコンクリート中の含水 状態を数値解析により求め, 測定データとの一致性を示 している。しかしながら，実際のコンクリートスラブは 打設初期から水和の進行と同時に乾燥が生じる場合が一 般的であり,それらを総合的に検証している例は少ない。

以上より，本研究は仕上げ材に直接影響を及ぼすと考 えられる仕上げ材施工後のコンクリートの含水状態が主 題であるが, その前提としての乾燥途中におけるコンク リートの含水状態についても十分な検討を要すると考え られる。本報では，水和の進行と乾燥が同時に生じる顕 著な場合として，打設直後からのコンクリートの乾燥に ついて検討することとし，コンクリートの含水状態を空 げき湿度および含水率分布測定により明らかにし，さら
* 東京工業大学 助手・工修

** 東京工業大学 助教授. 工博

*** 東京工業大学 教授. 工博
Research Associate of Tokyo Institute of Technology Associate Prof. of Tokyo Institute of Technology, Dr. Eng. Prof. of Tokyo Institute of Technology, Dr. Eng. 
に, 数值解析による含水状態の予測を試みる。なお,こ こで空げき湿度とは, 湿度センサーで測定可能なコンク リート中の小空間の相対湿度を意味している。

\section{2. 試験体}

コンクリート試験体は乾燥条件の悪いデッキプレート 上のスラブを想定して作製するものとした。コンクリー トの調合条件は表一1に示すものとし, 目標スランプは $18 \mathrm{~cm}$ とした。試験体は以下の 2 種類とした。

\section{1 空げき湿度測定用試験体}

型枠は直径 $30 \mathrm{~cm}$, 高さ $15 \mathrm{~cm}$ のプラスチックシリン ダーに底板を取り付けたものを使用した。コンクリート 打設時に表面から $0.65,1,2 ， 4 ， 7.5 ， 14 \mathrm{~cm}$ の位置 に湿度測定孔を設けた（図一1）。打設したコンクリート は型枠のまま以後の試験体とした。

\section{2 含水率測定用試験体}

型枠は直径 $10 \mathrm{~cm}$, 高さ $15 \mathrm{~cm}$ のプラスチックシリン ダーをあらかじめ 7 層に分割しておいたものを使用した (図一2)。型枠はコンクリートを打設しながら, 各層に 金網を㨀入し，順次重ねて厳重にテーピングし，一体化 した。また, 型枠とコンクリートの微小隙間からの乾燥 防止のために，コンクリート打設前に型枠内面にコンク リート打ち継ぎ用のエポキシ樹脂を塗布しておき，コン クリート硬化後の側面はエポキシでシールされるように 工夫した。これらの処置は, 含水率分布測定の際にコン クリートをたがね（鋉）で簡単に分割できるようにする ためであり，種々検討した結果採用した方法である。な

Table 1. Mix proportion of concrete

\begin{tabular}{lccccc}
\hline$W / C$ & $W$ & $C$ & $S / a$ & $S$ & $G$ \\
\hline $60 x$ & $192 \mathrm{~kg} / \mathrm{m}^{3}$ & $320 \mathrm{~kg} / \mathrm{m}^{3}$ & 47.54 & $824 \mathrm{~kg} / \mathrm{m}^{3}$ & $1005 \mathrm{~kg} / \mathrm{m}^{3}$ \\
\hline
\end{tabular}

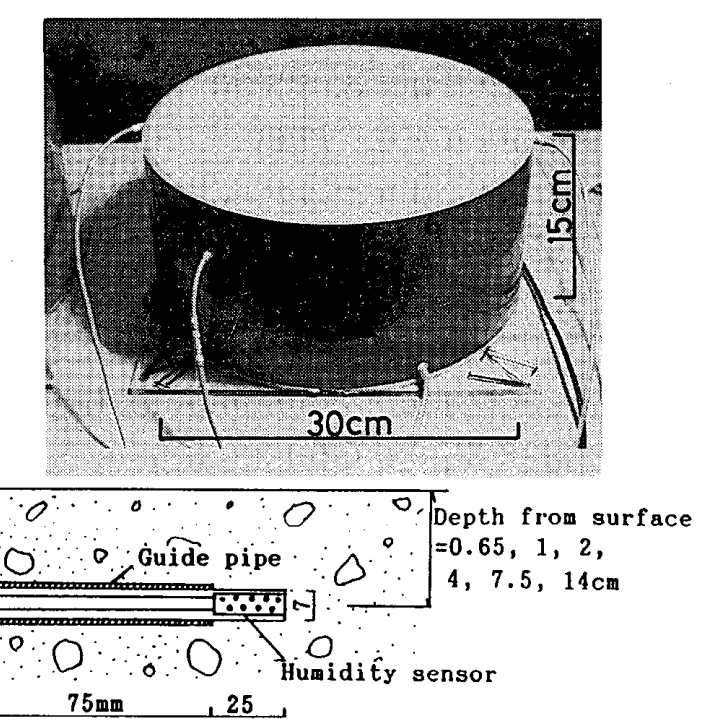

Fig. 1. Concrete specimen for measuring pore humidity and humidity sensor into the hole

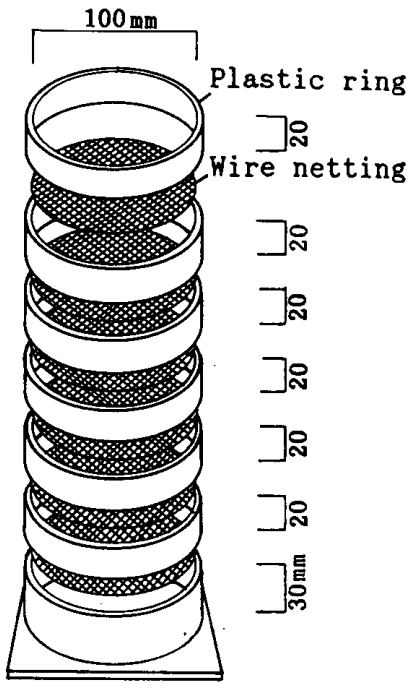

Fig. 2. One set of a mold of concrete for measuring moisture content

お，含水率測定用試験体の一部は予備実験で空げき湿度 変化も測定し, その結果, 空げき湿度測定用の試験体亡 の差はなく，試験体の大きさ，金網による湿分移動への 影響が小さいことを確認した。

\section{3. 実験および測定概要}

実験は $20^{\circ} \mathrm{C}, 40 \% \mathrm{RH}$ および $20^{\circ} \mathrm{C}, 80 \% \mathrm{RH} の 2$ 種類の恒温恒湿下で行った。コンクリートの空げき湿度 は電気抵抗式の湿度センサーを用いて測定した。測定時 以外は測定孔はシリコーンゴムの栓をしておき，測定の 際にセンサーを穴に挿入し，平衡状態になった時の湿度 を読み取った。また，湿度センサーは適時校正した。

一方, 含水率測定用試験体は, 所定の乾燥後, たが水 で迅速に 7 層に分割し, 各層の重量を測定した。その後 $105^{\circ} \mathrm{C}$ のオーブンでコンクリートを絶乾とし，その重量 差より重量含水率を求めた。含水率は 3 体の平均值とし た。

\section{4. 測定結果}

図一3に低湿環境下 $(40 \% \mathrm{RH})$ および高湿環境下 $(80 \% \mathrm{RH})$ での乾燥に伴うコンクリートの空げき湿度 分布変化を示す。乾燥は表層部加ら徐々に内部に進行す るが, 表層部の乾燥が早いのに対し, 内部の乾燥は非常 に遅い。高湿度における測定精度はやや低いと思われる が, 深さ $14 \mathrm{~cm}$ で $100 \% \mathrm{RH}$ より小さくなるのは, 高 湿環境で 79 日, 低湿環境で 35 日目であった。一年後に おいても，最深測定部は高湿環境で $92 \% \mathrm{RH}$ ，低湿環 境で $76 \% \mathrm{RH}$ となっている。また, 低湿環境で乾燥が 早く進行しているが, 1 年後において, 表層と最深測定 部の湿度差は高湿環境で約 $10 \% \mathrm{RH}$ なのに対し，低湿 環境では約 $35 \% \mathrm{RH}$ と大きく, 環境湿度による湿度分 布形態の差が顕著である。 

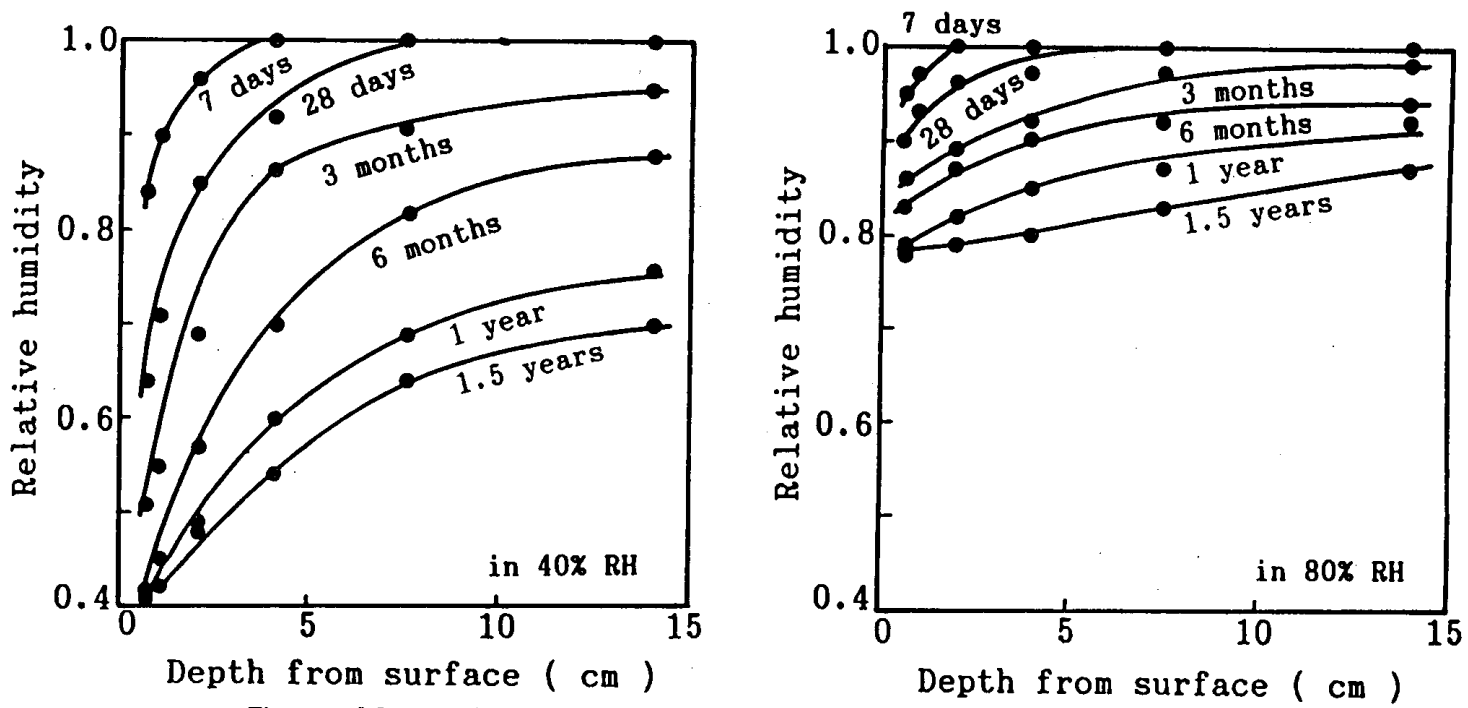

Fig. 3. Measured distribution of pore humidity in concrete during drying
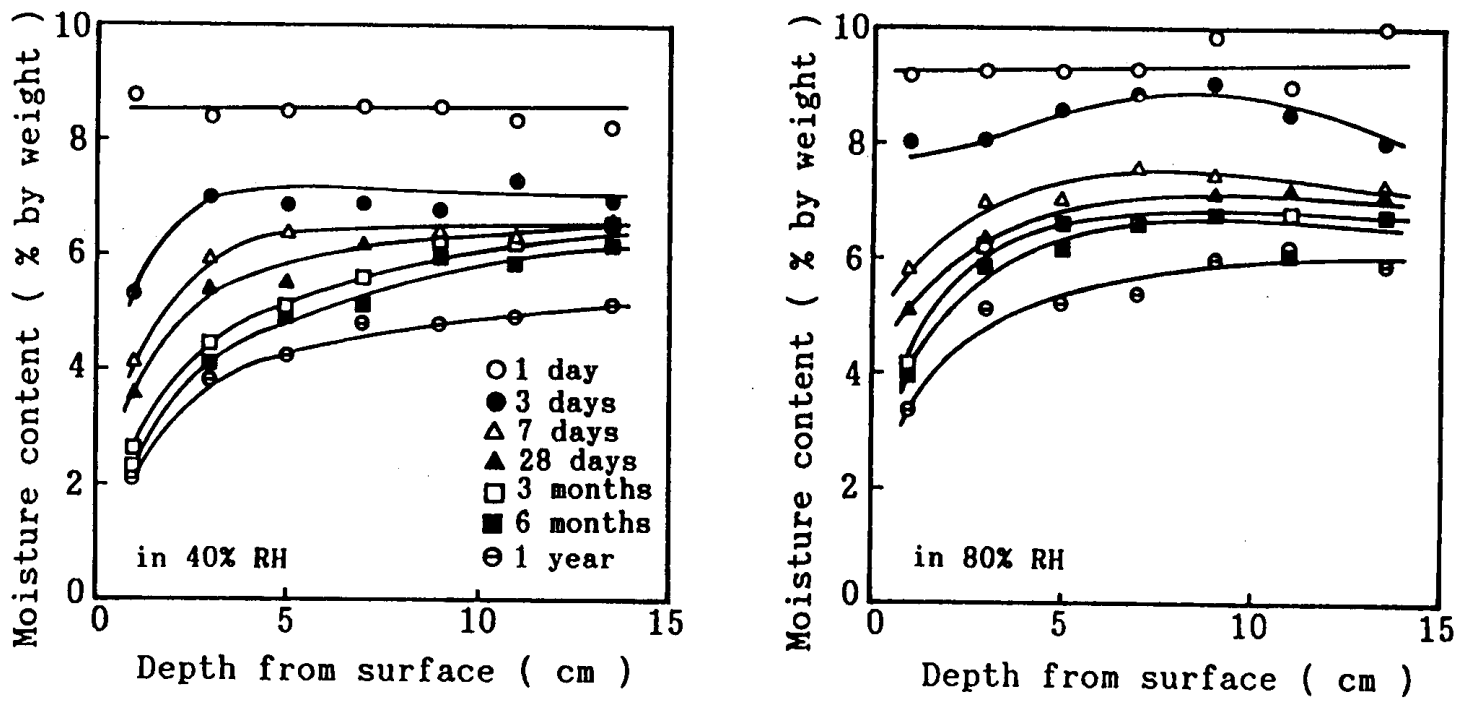

Fig. 4. Measured distribution of moisture content in concrete during drying

次に, 図一4に含水率分布の変化を示す。乾燥の進行 状況の概要は湿度分布とほぼ同様といえる。しかしなが ら,詳細には湿度分布とやや異なった状況を示している。 打設後数日は水分減少が非常に早く，しかも，低湿環境 で 1 日, 高湿環境で 3 日目まで表層から深部までの水分 勾配はほとんどない。これは，七メントの水和による減 少の外に, コンクリートの組織が非常に粗で，水分移動 がかなり自由であるために，表層からの水分蒸発が深部 にまで平均的に水分減少をもたらすためと考えられる。 そのため,この時点で全体的な含水率は低湿環境のほう が高湿環境より，約 $1 \%$ 低くなっている。1 年後におい ても, 内部の含水率は低湿環境で約 $5 \%$, 高湿環境で約 $6 \%$ であり, 乾燥程度の差には打設直後の初期水分蒸 発量の影響が大きい。しかし，湿度分布と比べ，環境湿 度による含水率の分布形態の差はあまり顕著ではない。

5. 仕上げ材下地としてのコンクリートの含水状態

以上の結果より，コンクリートスラブでは表面が乾燥
しているようにみえても, 内部は高含水状態が長期間続 くことが明らかである。したがって，仕上げ材施工後は 内部の高含水状態の影響を受けると想定され，仕上げ材 下地を前提とすると, 表面の乾燥程度だけで必ずしも安 全とはいえないことがわかる。また，乾燥収縮や応力の 観点からは表面の乾燥状態と内部の差がより大きい場合 が問題といえるが，仕上げ材下地としては，コンクリー 卜全体の含水量が少ない方が望ましく, 低湿環境でより 長期間乾燥することが仕上げ材の欠陥防止の基本である といえよう。ただし，一般論として，材令初期の乾燥は コンクリートの表層組織の緻密化を阻害し，仕上げ材の 欠宿に関与することも考えられるので，注意を要する。

\section{6. 乾燥過程における含水状態の数值解析}

\section{1 基本モデル}

本解析で対象とするのは，コンクリートの打設直後か ら水和と乾燥が同時に進行するモデルである。既往の研 究で同条件のモデルが示されている例はない。しかしな 
がら, 本解析への適応性が高いと考えられるものとして， Bažant らの解析手法 ${ }^{2}$ が挙げられる。彼らが提案してい る乾燥に伴うコンクリート中の空げき湿度 $H$ は次式に 従う。

$$
\frac{\partial H}{\partial t}=\operatorname{div}(D \operatorname{grad} H)+\frac{\partial H_{s}}{\partial t}
$$

ここで $D$ は拡散係数であり， $H_{s}$ は水和に伴う湿度低下 で自己乾燥と呼ばれる。

（1）式は湿度勾配を水分移動のポテンシャルとして いることから, 乾燥が生じる以前にある程度水和が進行 し, コンクリートの含水量が初期值 $100 \% \mathrm{RH}$ にぼ 対応する場合に有効であると考えられる。コンクリート の打設直後や，ごく初期材令での湿気飽和状態の含水量 に対して初期值 $100 \% \mathrm{RH}$ を仮定すると明らかに乾燥 が速すぎる。そこで, 本解析では（1）式を基本とし， さらに, 打設直後からの乾燥を考虑した初期材令モデル を導入し, 実測值との比較からその有効性を検証するこ とにする。

\section{2 初期材令モデル}

コンクリートの打設直後から乾燥が生じる場合の初期 材令モデルとして以下の仮定をする。

(1)打設後 1 日は，環境条件に応じて表面からある量の 水分が蒸発し，コンクリート全体の水分は瞬時に均一化 するものとし, 打設 1 日後の水分状態を拡散計算上の初 期值とする。

(2)その後の湿気飽和状態では, 含水量に対応する仮想 湿度（数值解析上の $100 \% \mathrm{RH}$ 以上の仮の湿度）を設 定し，仮想湿度領域を含めた湿度勾配をポテンシャルと し，（1）式により水分移動をモデル化する。

ここで, (1)の仮定は実験結果と対応するものであり, (2)は論理的ではないが, 実現象に沿い，かつ簡便な解析 とするためのものである。

(1)より，コンクリートの体積含水率の初期值 $w_{i}$ は一 律につぎのようになる。

$$
w_{i}=W-w_{n 1}-w_{0}
$$

$W$ : 調合時の単位容積当たりの水量（骨材の含有水量 を含む)

$w_{n 1}$ : 打設後 1 日の単位容積当たりの結合水量

$w_{0}$ : 打設後 1 日の単位容積当たりの水分蒸発量

ここで, 打設後 1 日の水分蒸発量は環境湿度, 風速, 温 度等で変化するが, 今回は解析の有効性を検証する目的 から, 実験時の試験体の重量減少量をそのまま用いるこ ととする。ただし, その平均湿気伝達率は, 微風速下 の低湿環境で $21 \mathrm{~g} / \mathrm{m}^{2} \mathrm{hmmHg}$, 高湿環境で $28 \mathrm{~g} / \mathrm{m}^{2}$ $\mathrm{hmmHg}$ であり, 水の自由表面からの值 $25 \sim 30 \mathrm{~g} / \mathrm{m}^{2}$ $\mathrm{hmmHg}^{11)}$ に近いものであったこと, 水セメント比約 50 $\%$ ，スランプ $2.5 \mathrm{~cm}$ の硬練りコンクリートにおける打 設後 1 日間の平均湿気伝達率は約 $10 \mathrm{~g} / \mathrm{m}^{2} \mathrm{hmmHg}$ であ
り，風速が $5 \mathrm{~m} / \mathrm{sec}$ となると約 2 倍になるとの報告 ${ }^{12)}$ よ゙は，一般的な設定の可能性を示すものである。

また，(2)の仮定に基づき，後述のようにコンクリート の空げき湿度と含水率の関係を設定し, その関係と $w_{i}$ より空げき湿度の初期値 $H_{i}$ が決定される。

\section{3 空げき湿度と含水率の関係}

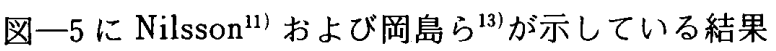
から求めた乾燥過程における湿度と体積含水率の関係

(等温脱着曲線) を示す。Nilssonによれば，この関係 は $W / C=60 \%$, 水和率 0.8 程度に当てはまる。図には 筆者らの実験から得られた含水率とそれに対応する空げ

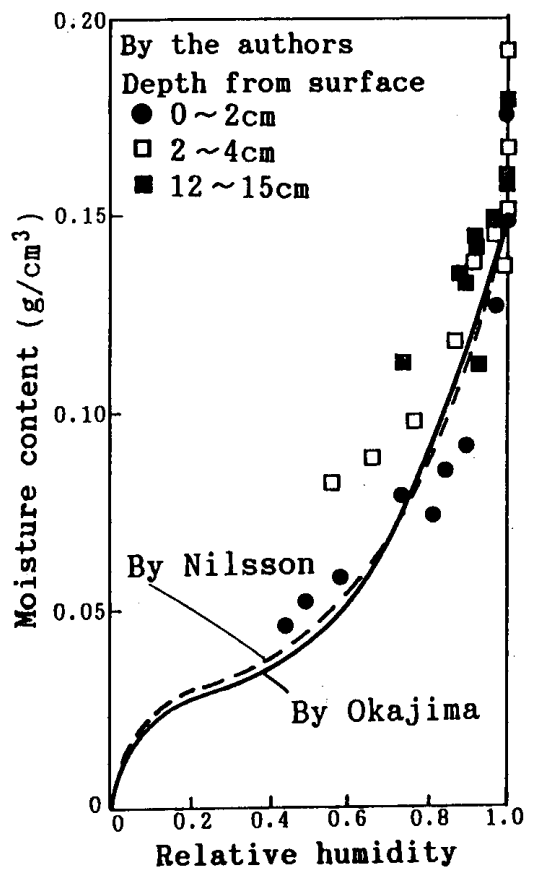

Fig.5. Desorption isotherms of concrete according to Okajima et al. and Nilsson, and present experimental results

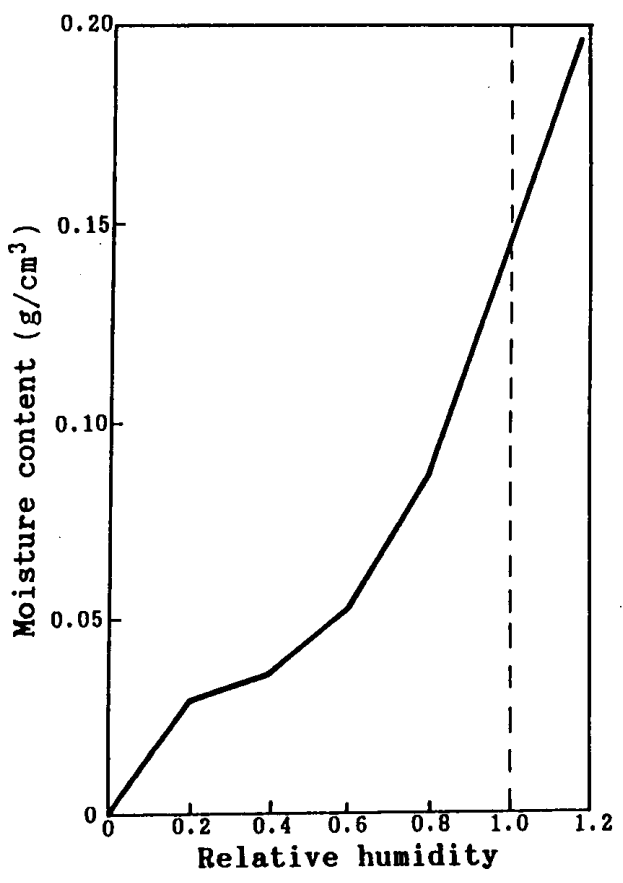

Fig. 6. Used desorption isotherm 
き湿度のデータの例も示してある。全体的には筆者らの データと彼らの示す関係はかなり一致しており，W/C $=60 \%$ 程度のコンクリートの典型的な関係として利用 できると思われる。この関係を直線近似し，図一6に示 す湿度と含水率の関係を解析に用いた。仮想湿度領域は 高湿度の関係をそのまま直線外挿して仮定している。こ の図より，コンクリートの空げき湿度と含水率の変換が できる。

\section{4 自己乾燥}

セメントの水和の進行は $80 \% \mathrm{RH}$ 以下では非常に小 さくなることから，Bažant ら ${ }^{2)}$ は水和率は材令ではな く, 有効材令から求めることを提案している。有効材令 とは湿度に対する材令の低減を考慮したもので，低減率 $\beta_{H}$ は図一7のようになり，コンクリート打設後 1 日経て からの時刻 $t$ における有効材令 $t_{e}$ （初期值=1日）は 次式となる。

$$
t_{e}=\int_{0}^{t} \beta_{H} d t+1 \quad(\mathrm{day})
$$

また，結合水量は，既往の研究 ${ }^{14), 15)}$ を参考に最終結 合水量を単位セメント量の $25 \%$ とし, Copeland らの データ ${ }^{16)}$ 基づいて図一 8 のように定めた。したがって, 結合水量 $w_{n}$ は

$$
w_{n}=0.25 C\left(1-0.636 t_{e}^{-0.347}\right) \text {. }
$$

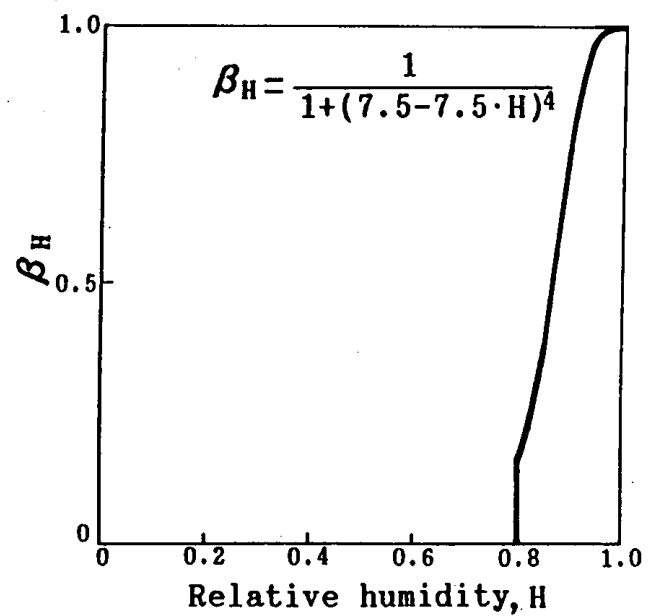

Fig. 7. Dependence of relative hydration rates on humidity according to Bažant et al.

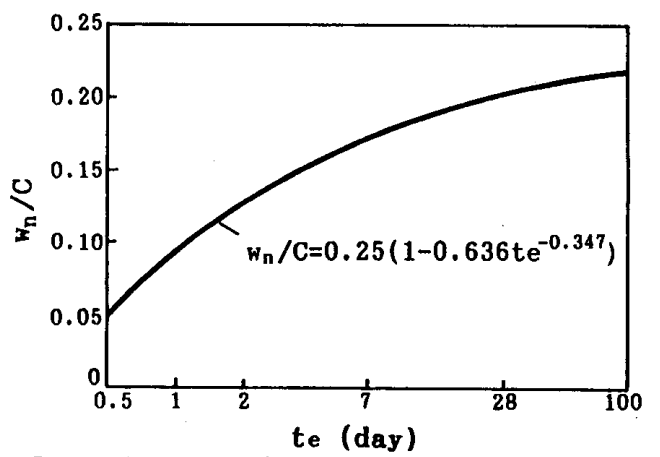

Fig. 8. Increasing rate of bound water in Portland cement paste as a function of age (te)

\section{$C$ : 単位セメント重量}

となり, 結合水量の増加に伴う自己乾燥 $H_{s}$ は次式から 求める。

$$
d H_{s}=-k d w_{n}
$$

$k:$ 図一6 の直線の傾きの逆数

\section{5 拡散係数}

拡散係数の有効材令に対する依存性について Bažant ら ${ }^{2)}$ は次式を提案している。

$$
D_{0}\left(t_{e}\right)=D_{10}\left(1+10 / t_{e}\right)
$$

ここで $D_{10}$ は定数である。解析では，有効材令 28 日以 降は $D_{0}$ が一定值 $\left(0.25 \mathrm{~cm}^{2} /\right.$ day $)$ となるように

$$
\left.\begin{array}{ll}
t_{e}<28 \text { 日で } & D_{0}=0.184\left(1+10 / t_{e}\right) \\
t_{e} \geqq 28 \text { 日で } & D_{0}=0.25
\end{array}\right\}
$$

とした。ここで拡散係数 $0.25 \mathrm{~cm}^{2} /$ day は最も典型的と 考えられる値である。図一 9 にこの関係を示す。

また，拡散係数の含水量に対する依存性についてはい くつかの報告があるが(2)-4),9),11)，いずれも Bažant ら²) が示しているものと傾向は似ている。図一10 はその関 係を示すもので，拡散係数 $D$ が湿度 $H$ に依存し，関係 式は次式となる。

$$
D(H)=D_{0}\left\{\alpha_{0}+\frac{1-\alpha_{0}}{1+\left(\frac{1-H}{1-H_{c}}\right)^{n}}\right\}
$$

ここで, $\alpha_{0}=0.05, H_{c}=0.75, n=16$ が Bažant ら $ら^{2)}$ が 提案している代表的な值であり， $D_{0}$ は（7）式による。 しかし，結果的には，以上の拡散係数の材令依存性，湿 度依存性を用いて数值解析を行うと, 特に, 高湿環境

$(80 \% \mathrm{RH})$ におりる初期材令での乾燥が実測值より かなり速いものとなった。Bažant ら゙によれば，（8） 式で $H_{c}$ を境に拡散係数が急変するのはコンクリート毛 細管の水の満され方に依存している。そこで, 初期材令 では毛細管径が太いことから， $H_{c}$ がより大きいという 仮定を導入し，㟻定的に $H_{c}=0.85$ と修正する。これに より, 高湿環境でも乾燥面近傍の拡散係数は相対的に非

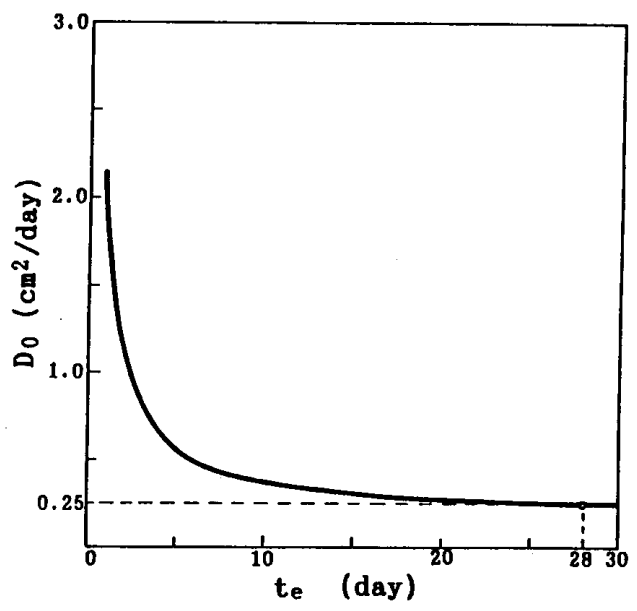

Fig. 9. Dependence of diffusivity on age (te) 
常に小さくなり, 乾燥速度が低下する。この仮定は有効 材令が進行すれば $H_{c}$ は 0.75 に近づくことも意味する が, その変化を考慮すると, 湿度 $80 \% \mathrm{RH} \sim 90 \% \mathrm{RH}$ のコンクリート層は有効材令の進行とともに拡散係数が 増大する場合も生じることになり， $H_{c}$ 変化の安易な設 定はこれまで述べた拡散係数の材令依存性, 湿度依存性 の有効性を損なう可能性がある。以上より, 今回は材令 によらず $H_{c}=0.85$ 一定とし, 特に初期材令に重点を置 いた解析とする。

$H_{c}=0.85$ とし, 仮想湿度領域も含めた拡散係数の湿 度依存性を同じく図一-10に示す。仮想湿度領域の拡散 係数は単純に 90〜 100\% RH のそれと同一と仮定した。 6.6 境界条件

コンクリート乾燥面の境界条件として, 含水率勾配を 水分移動のポテンシャルとしている研究では表面係数を 用いた境界条件式を設定する例が多( 1),3),7),9),10)。本解 析でも湿気伝達率を用いて同等な境界条件式が可能であ るが, 水和進行中の表面係数や湿気伝達率は非常に曖味 な係数と言わざるを得ず，むしろ；乾燥面は環境湿度に 等しいとする方が妥当と考えられる。故に，ここでは，

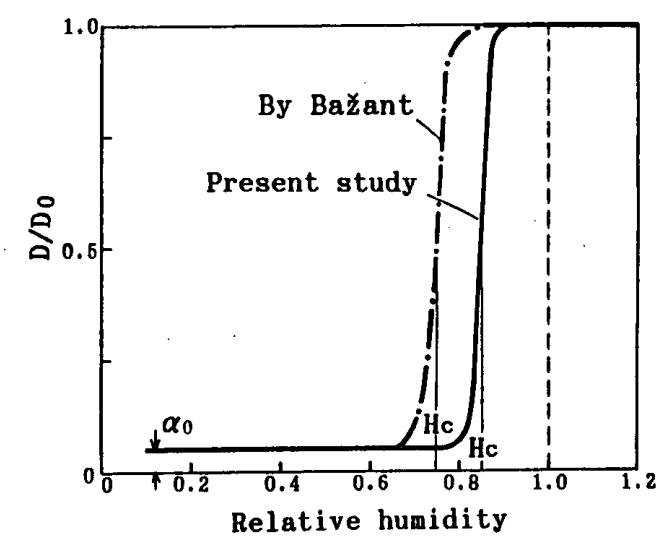

Fig. 10. Dependence of diffusivity on relative humidity

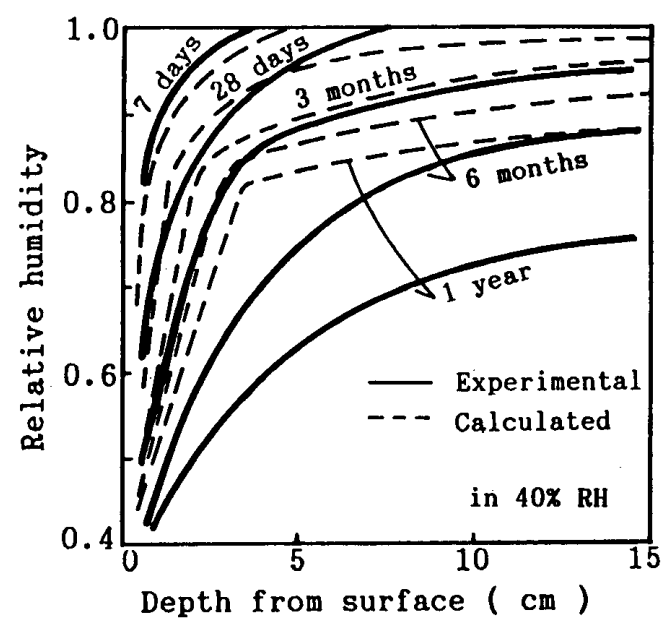

拡散計算におけるコンクリートの乾燥面は環境湿度に等 しいものとした。

\section{7 計算式}

(1) 式を Clank-Nicolsonの差分により計算する。 (1) 式の差分式は, $p=\frac{\Delta t}{2 \Delta x^{2}}$ とし, 次のようになる。

$$
\begin{aligned}
& H_{n+1, m}-H_{n, m}=p \mid D_{m+1 / 2}\left(H_{n+1, m+1}-H_{n+1, m}\right. \\
& \left.+H_{n, m+1}-H_{n, m}\right)-D_{m-1 / 2}\left(H_{n+1, m}\right. \\
& \left.\left.-H_{n+1, m-1}+H_{n, m}-H_{n, m-1}\right)\right\} \\
& +d H_{s m}
\end{aligned}
$$

ここで, $\Delta t:$ 分割時間 $\Delta x:$ 分割幅

$H_{n, m}$ : 時間 $n \Delta t$, 位置 $m \Delta x$ における湿度

$D_{m+1 / 2}$ : 位置 $m \Delta x,(m+1) \Delta x$ 間の拡散係数

$d H_{s m}$ : 位置 $m \Delta x$ における時間 $\Delta t$ 間の自己乾燥

また, 体積含水率 $w_{e}$ は計算された湿度と図一6の関 係より求め, 重量含水率 $w_{w}$ は次式より求めた。

$$
w_{w}=w_{e} /\left(C+A+w_{n}\right) \cdots
$$

ここで, $C:$ 単位セメント重量

$$
\begin{gathered}
A: \text { 単位骨材絶乾重量 } \\
w_{n} \text { : 単位結合水量 }
\end{gathered}
$$

\section{8 計算結果}

計算結果を図一 11,12 に示す。湿度計算では高湿環 境下で計算值と実測值はほぼ一致している。しかし，低 湿環境下では 3 力月を過ぎてから計算值は実測値よりも かなり大きくなっている。含水率計算においては，湿度 計算とは逆に，低湿環境下で計算值と実測値がよく一致 しているのに対し，高湿環境下では数力月以降，特に表 面付近の含水率分布に差が生じている。このように乾燥 が長期間の場合に環境湿度の違いで計算值の合致性が異 なっているのは, 初期材令に重点を置いて（8）式の $H_{c}$ を 0.85 としていること, 湿度と含水率の関係が恒常 的に成り立たないこと，などのためと思われ，解析手法 の限界を示しているようである。しかしながら，数力月 程度までの乾燥においては, 湿度分布および含水率分布

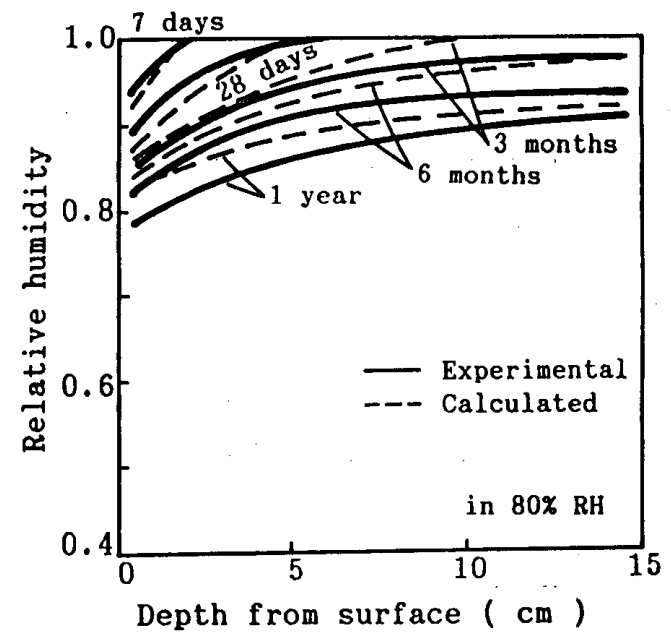

Fig. 11. Comparison between experimental and calculated. humidity distribution during drying 


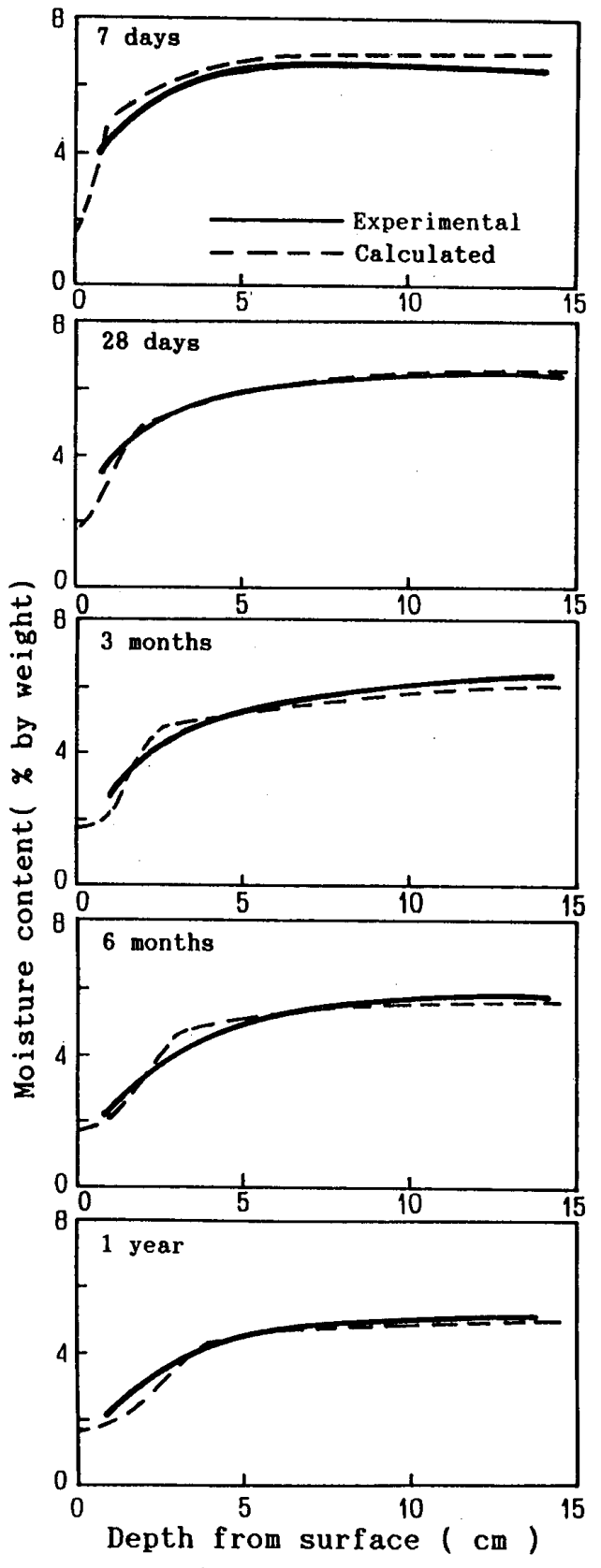

(a) in $40 \% \mathrm{RH}$

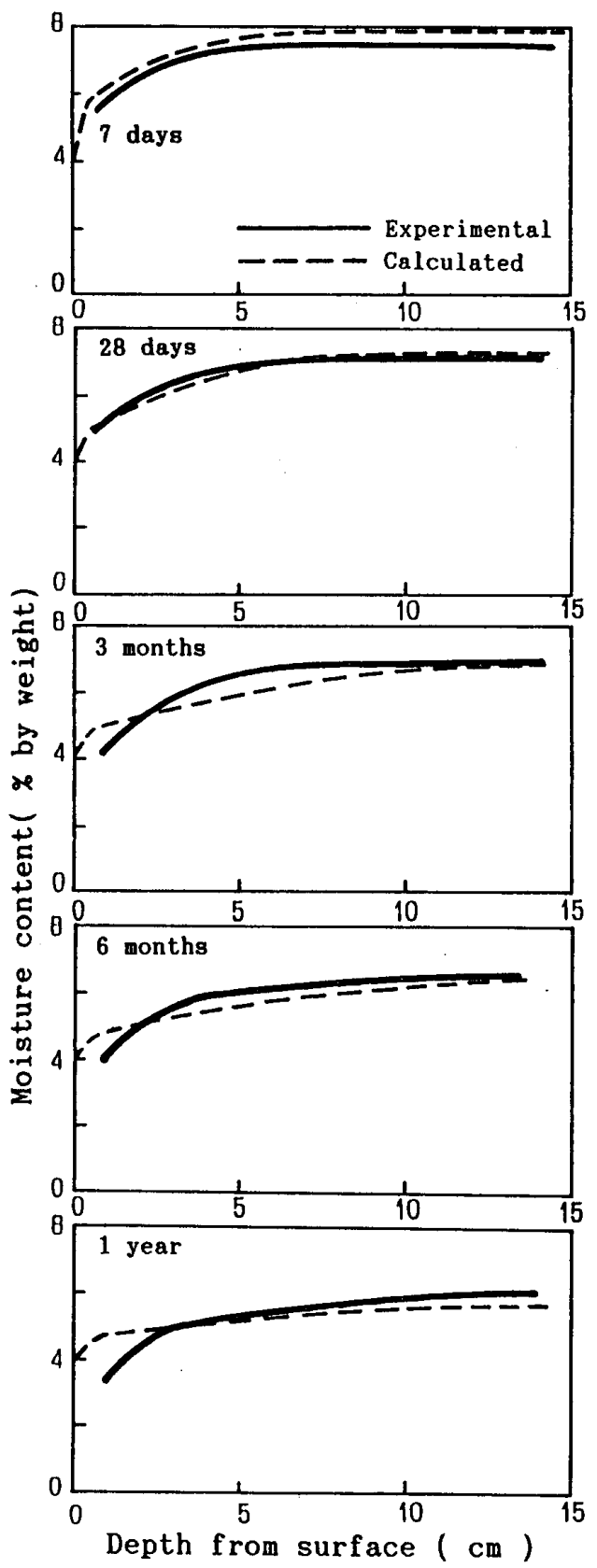

(b) in $80 \% \mathrm{RH}$

Fig. 12. Comparison between experimental and calculated moisture content distribution during drying

ともかなり良い予測ができ，仕上げ材下地としてのコン クリートは乾燥期間が短い場合が主に問題となることか ら，対象を乾燥初期に限定すれば本解析治有効であると 考えられる。

\section{7. おわりに}

本報では，仕上げ材へ影響を及ばすと考えられる下地 コンクリート中の含水状態について基礎的な検討を行 い，打設直後からの乾燥期間中のコンクリート含水状態 について以下の知見が得られた。

1）コンクリート中の空げき湿度分布および含水率分 布の両測定結果加ら，打設直後加ら水和の進行之同時に
乾燥が生じる場合のコンクリート内部の水分挙動を明ら かにした。

2）コンクリート表層の乾燥が早いのに比べ，内部は 高含水状態が長期間続くこと, また，環境湿度の違いに よる乾燥状態の差が顕著であることが確かめられた。

3）仕上げ材下地を前提とすると，コンクリートはよ り低湿環境で長期間乾燥することが基本であると考えら れる。

4） Bažant ら²) の解析手法を基本とし，さらに，初 期材令モデルを導入して，打設直後から乾燥が生じる場 合のコンクリート内部含水状態の数值解析例を示し, 乾 燥期間が数力月以内であれば, 実験結果とほぼ一致する 


\section{ことを示した。}

\section{謝 辞}

本研究を進めるに当たり，佐藤慎一氏（当時東京工業 大学大学院生, 現旭化成工業 (株)) の全面的な協力を 得ました。ここに謝意を表します。また，研究費の一部 に文部省科学研究費を使用しました。関係者各位に御礼 申し上げます。

\section{参考文献}

1) Pickett, G. : Shrinkage Stresses in Concrete, Jounal of ACI, Vol.17, No.3, pp. 165 204, 1946

2) Bažant, Z.P. \& Najjar, L. J. : Nonlinear Water Diffusion in Nonsaturated Concrete, Materiaux et Constructions, Vol.5, No. 25, pp.3 20, 1972

3）阪田憲次, 蔵本 修：乾燥に伴うコンクリート中の水分 の逸散と乾燥収縮に関する研究, 土木学会論文報告集, 第 316 号, pp. 145 152, 1981

4) Pihlajavaara, S.E. : On the Main Features and Methods of Investigation of Drying and Related Phenomena in Concrete, (State Inst. for Techn. Research), Helsinki, Ph. D. Thesis, Publ. No.100, 1965

5) 原田 有, 仕入豊和, 椎名國雄：乾燥に伴うコンクリ一 卜部材の湿気こう配に関する研究，セメント技術年報 23 , pp. $297 \sim 301,1969$

6）後藤幸正, 藤原忠司, 飯泉 章: 乾燥過程におけるコン クリート内部の含水状態について，セメント技術年報 29 , pp. $175 \sim 178 ， 1975$

7）永松靜也,佐藤嘉昭：非線形拡散方程式によるコンクリー 卜の脱水量の分布に関する研究，七メント技術年報 35 , pp. $162 \sim 165,1981$
8）桜井正幸, 前田孝一：コンクリート中の湿度分布の予測 に関する研究 (有限要素法による非線形拡散方程式の解 法の適用), 日本建築学会大会学術講演梗概集-構造系, pp. 127 128, 1983

9) Mensi, R., Acker, P. \& Attolou, A. : Sechage dubeton-Analyse et modelisation, Materials and Structure, Vol. 21, pp. 3 12, 1988

10）滝口克己, 堀田久人, 小板橋裕一：若材令コンクリート の熱及び乾燥による応力解析法, 日本建築学会構造系論 文報告集，第 396 号，pp. 118～124，1989

11) Nilsson, L-O. : Hygroscopic Moisture in Concretedrying, Measurements \& Related Material properties, Report TVBM-1003, Lund Sweden, 1980

12）戸川一夫, 中本純次：コンクリートの初期収縮ひびわれ と水分蒸発速度との関係，七メント技術年報 $28, p p .314$ $\sim 317,1974$

13）岡島達雄, 水谷章夫, 河辺伸二, 志村欣一, 加知由次： コンクリートの等温吸脱着特性, 第 43 回セメント技術大 会講演集, pp. $350 \sim 353,1989$

14) Powers, T.C. \& Brownyard, T.L. : Studies of the Physical Properties of Hardened Portland Cement Paste, Bulletin 22, Poltland Cement Assn., Chicago, 1948

15）河角 誠, 関 慎吾, 笠原, 清, 栗山武雄 : セメントの 水和と内部水の粘性からみたコンクリートのクリープ特 性, 土木学会論文集, 第 321 号, pp. 167 175, 1982

16) Copeland, L.E. \& Kantro D. L. : The Chemistry of Cement, Ed. Taylar, F.W., Vol.1, Academic Press, London, p. 352, 1964

(1989 年 10 月 28 日原稿受理, 1990 年 4 月 7 日採用決定) 